\title{
Correction to: Stephen Scher and Kasia Kozlowska: Rethinking health care ethics
}

\section{Palgrave Macmillan, Singapore, 2018, 169 pp, \$31,} ISBN: 978-981-13-0829-1

\section{Patrick Daly ${ }^{1}$}

Published online: 3 October 2019

(c) Springer Nature B.V. 2019

\section{Correction to: Theoretical Medicine and Bioethics https://doi.org/10.1007/s11017-019-09493-w}

The originally published review of this book did not include the information that an electronic version is available for download free of charge via open access from Palgrave MacMillan at https://www.palgrave.com/us/book/9789811308291 (ISBN 978-981-13-0830-7).

Publisher's Note Springer Nature remains neutral with regard to jurisdictional claims in published maps and institutional affiliations.

The original article can be found online at https://doi.org/10.1007/s11017-019-09493-w.

\section{Patrick Daly}

dalypp@bc.eduss

1 Lonergan Institute at Boston College, Chestnut Hill, MA, USA 